\title{
Fuel Cell Electrolytes of Polybenzimidazole Membranes Cross-linked with Bis(chloromethyl) Arenes
}

Kirkebæk, A.; Aili, D.; Yue, B.; Vassiliev, A.; Cleemann, L. N.; Jensen, J. O.; Li, Q.

Published in:

Fuel Cells

Link to article, DOI:

10.1002/fuce.201800090

Publication date:

2018

Document Version

Peer reviewed version

Link back to DTU Orbit

Citation (APA):

Kirkebæk, A., Aili, D., Yue, B., Vassiliev, A., Cleemann, L. N., Jensen, J. O., \& Li, Q. (2018). Fuel Cell

Electrolytes of Polybenzimidazole Membranes Cross-linked with Bis(chloromethyl) Arenes. Fuel Cells, 18(6), 688-697. https://doi.org/10.1002/fuce.201800090

\section{General rights}

Copyright and moral rights for the publications made accessible in the public portal are retained by the authors and/or other copyright owners and it is a condition of accessing publications that users recognise and abide by the legal requirements associated with these rights.

- Users may download and print one copy of any publication from the public portal for the purpose of private study or research.

- You may not further distribute the material or use it for any profit-making activity or commercial gain

- You may freely distribute the URL identifying the publication in the public portal 


\title{
Fuel cell electrolytes of polybenzimidazole membranes cross-
}

\section{linked with bis(chloromethyl) arenes}

Andreas Kirkebæk $^{1}$, David Aili ${ }^{1 *}$, Bauhua Yue ${ }^{1,2}$, Anton Vassiliev ${ }^{1}$, Lars N. Cleemann ${ }^{1}$, Jens Oluf ${ }^{1}$ Jensen and Qingfeng $\mathrm{Li}^{1}$

${ }^{1}$ Technical University of Denmark, Department of Energy Conversion and Storage, Elektrovej, Building 375, 2800 Kgs. Lyngby, Denmark

${ }^{2}$ Shanghai University, Department of Chemistry, 99 Shangda Road, Shanghai 200444, China

[*] Corresponding author: larda@dtu.dk

\begin{abstract}
Cross-linking of phosphoric acid doped polybenzimidazole membranes as fuel cell electrolytes represents an attractive approach to improving the mechanical robustness at a high acid loading. Numerous cross-linking concepts have been reported in the literature, but a deeper understanding of how the cross-linking chemistry affects the physicochemical properties of the membrane and its fuel cell performance and durability remains to be assessed. In this work a series of cross-linked membranes are prepared using cross-linking agents of different regiochemistry and steric nature. It is shown that the nature of the cross-linking agent has a large impact on the effective degree of cross-linking, which in turn determines the acid doping characteristics and ultimately the fuel cell performance and acid retention during long-term operation.
\end{abstract}

Keywords: Polybenzimidazole, cross-linking, proton conductor, membranes, fuel cells, durability 


\section{Introduction}

Membranes based on phosphoric acid imbibed heteroaromatic polymers such as polybenzimidazoles $[1,2]$ or pyridine containing polysulfones [3] have emerged as the stateof-the-art electrolyte materials for polymer electrolyte membrane fuel cells operating in the temperature range of $120-200{ }^{\circ} \mathrm{C}$. While the phosphoric acid supports high proton conductivity at low water activities [4], the high operating temperature opens for good tolerance towards fuel impurities [5]. From a technological point of view, this allows for robust systems with simple auxiliary units and with good possibilities for thermal integration of fuel processing units $[6,7]$.

$\operatorname{Poly}\left(2,2^{\prime}\right.$-(m-phenylene)-5,5'-bibenzimidazole) (PBI) is the most thoroughly studied base-polymer in this connection, and it is a general understanding that the proton conductivity increases with increasing phosphoric acid content of the membrane [1]. Maximizing the phosphoric acid content of the membrane is thus the most straightforward approach to reducing the internal resistance [8]. However, the phosphoric acid tend to redistribute $[9,10]$ or leach out [11-13] during operation, which represents a predominating degradation mode of the fuel cell performance. This is particularly severe at high current loads, at high gas flow rates and at temperature in the higher end of the operating temperature window [14]. Introduction of an inorganic phase, such as titanyl sulfate $[15]$, titania $[16,17]$ or mesoporous silica $[11,18]$ in the membrane matrix may stabilize the performance and extend the lifetime. Ideally, replacing the phosphoric acid with a solid-state proton conductor would be a rational strategy to mitigate this degradation mode. This is indeed an interesting concept, but it remains in an early research phase [19].

Another way to mitigate the degradation could be to increase the total phosphoric acid content within the membrane. This is, however, complicated by the strong plasticizing effect exerted by phosphoric acid, particularly at high temperatures [20] and under humid conditions 
[21]. In practice, this means that the acid content must be balanced against the mechanical strength of the membrane.

Much research has therefore been directed towards the development of new membrane structures that can maintain their mechanical robustness at high acid contents. Increasing the linear molecular weight of the polymer $[8,22]$ or reinforcing the structure with an inert phase [23] have proven successful in this connection. Covalent cross-linking is another effective approach and can be achieved in a non-specific manner by heat treatment of the pristine membranes at temperatures up to $350^{\circ} \mathrm{C}$ [24]. Better control of the degree of cross-linking and the chemistry involved can be obtained by reacting the polymer with electrophiles containing at least two functionalities such as $\alpha, \alpha^{\prime}$-dibromo- $p$-xylene [25], 1,3,5tris(bromomethyl)benzene [26], dichloromethyl phosphinic acid [27], divinyl sulfone [28], epoxides [29-33], silanes [34] or by employing Diels-Alder chemistry [35]. Recently, a sequential method for the preparation of polybenzimidazole network membranes was reported [36]. Furthermore, covalently cross-linked interpenetrating polymer networks have been prepared by blending and reacting PBI with halomethyl- $[37,38]$ or sulfonated polysulfone [39, 40], poly(vinylbenzyl chloride) [41], polybenzoxazine [42], or bromomethylated poly(aryl ether ketone) [43].

The reported cross-linking concepts indeed demonstrate that the dimensional stability is improved at high acid contents, but the understanding of how the stereo- and regio-chemistry of the cross-linking agent affects the physicochemical properties remains limited. To further explore this territory, cross-linked $m$-PBI membranes are in this work prepared using three cross-linking agents with different regio-chemistry and steric characteristics. Membranes with a degree of cross-linking of $10 \%$ were prepared and extensively characterized towards a better understanding of the structure-properties relationship of such materials. 


\section{Experimental}

\subsection{Materials}

3,3'-diaminobenzidine (DAB, $\geq 98 \%$ ) was acquired from Glentham Life Sciences and stored at $-18{ }^{\circ} \mathrm{C}$. Isophtalic acid (IPA, $99 \%$ ), benzimidazole (98\%), orthophosphoric acid (PA, 85\%), $\mathrm{H}_{2} \mathrm{O}_{2}$ (30\%, aq.), polyphosphoric acid (PPA, 115\% PA content, reagent grade), 1,4bis(chloromethyl)benzene (CLI, 98\%), 1,3-bis(chloromethyl)benzene (CLII, > 98\%), 2,4bis(chloromethyl)-1,3,5-trimethylbenzene (CLIII, 95\%), $\left(\mathrm{NH}_{4}\right)_{2} \mathrm{Fe}\left(\mathrm{SO}_{4}\right)_{2} \cdot 6 \mathrm{H}_{2} \mathrm{O}, \mathrm{H}_{2} \mathrm{SO}_{4}$ (96\%), N,N-dimethylacetamide (DMAc) were from Sigma-Aldrich. All chemicals were used as received and stored at ambient conditions unless otherwise noted.

\subsection{Model system}

In three flasks, benzimidazole $(0.5 \mathrm{~g}, 4.23 \mathrm{mmol})$ was dissolved in $8 \mathrm{~mL}$ DMAc. One of the cross-linking agents (CLI, CLII or CLIII, $2.12 \mathrm{mmol}$ ) was added to each flask to form homogeneous solutions. The solutions were refluxed at $170{ }^{\circ} \mathrm{C}$ for 2 hours and subsequently cooled to room temperature. The precipitates were collected and dried under vacuum at $110^{\circ} \mathrm{C}$ for 16 hours. 1,4-bis((1H-benzo[d]imidazol-1-yl)methyl)benzene (from CLI): Isolated in quantitative yield as a white solid; ${ }^{1} \mathrm{H}$ NMR (400 MHz, DMSO-d $) \delta 9.24(2 \mathrm{H}, \mathrm{s}), 7.86(2 \mathrm{H}$, m), $7.78(2 \mathrm{H}, \mathrm{d}, J=9.30 \mathrm{~Hz}), 7.71(2 \mathrm{H}, \mathrm{m}), 7.56(2 \mathrm{H}, \mathrm{q}, J=9.30 \mathrm{~Hz}), 7.43(4 \mathrm{H}, \mathrm{s}), 5.64(4$ H, s). 1,3-bis((1H-benzo[d]imidazol-1-yl)methyl)benzene (from CLII): Isolated in quantitative yield as a white solid; ${ }^{1} \mathrm{H}$ NMR (400 MHz, DMSO- $\left.d_{6}\right): 8.14$ (2 H, br. s), 7.84 (4 H, q, $J=9.10 \mathrm{~Hz}), 7.58$ (4 H, br s), 7.52 (1 H, s, ) 7.50 (3 H, br s). 1,1'-((2,4,6-trimethyl-1,3phenylene)bis(methylene))bis(1H-benzo $[d]$ imidazole) $\quad$ (from CLIII): $\quad$ Isolated in quantitative yield as a white solid; ${ }^{1} \mathrm{H}$ NMR (400 MHz, DMSO- $\left.d_{6}\right): 8.62$ (2 H, br. s), 7.80 (4 H, br s), 7.50 (4 H, br s), $7.21(1 \mathrm{H}$, br s), $5.63(4 \mathrm{H}, \mathrm{s}), 2.29(6 \mathrm{H}, \mathrm{s}), 2.22(3 \mathrm{H}, \mathrm{s})$. 


\subsection{Polymer synthesis and membrane fabrication}

The synthesis of PBI was adapted from literature [25, 35, 42], and a short description is presented here. DAB and IPA were dried at $110^{\circ} \mathrm{C}$ under argon overnight before charged in equimolar amounts $(34.58 \mathrm{~g} / 161.39 \mathrm{mmol}$ and $26.77 \mathrm{~g} / 161.13 \mathrm{mmol}$, respectively) to a dry reaction vessel equipped with an overhead mechanical stirrer, argon in- and outlets and a thermometer. PPA (2000 g) was then added and the mixture was stirred at $150{ }^{\circ} \mathrm{C}$ overnight. The temperature was raised to $220^{\circ} \mathrm{C}$ and the solution was stirred for $4 \mathrm{~h}$. The crude mixture was poured through a funnel into a beaker filled with deionized water $(10 \mathrm{~L})$, resulting in precipitation of fibers. The fibers were collected and treated extensively with large amounts of deionized water, aqueous $\mathrm{Na}_{2} \mathrm{CO}_{3}\left(1 \mathrm{~mol} \mathrm{~L}^{-1}\right)$ and deionized water again until neutral $\mathrm{pH}$. The fibers were subsequently dried at $110{ }^{\circ} \mathrm{C}$ overnight under vacuum. Yield: $49.2 \mathrm{~g}, 98.4 \%$. The inherent viscosity $\eta_{\text {inh }}$ was $1.54 \mathrm{dL} \mathrm{g}^{-1}$ at $30.0^{\circ} \mathrm{C}$, measured using an Ubbelohde viscometer with a sample concentration of $4.985 \mathrm{~g} \mathrm{~L}^{-1}$ in $96 \% \mathrm{H}_{2} \mathrm{SO}_{4}$.

For further processing, the PBI fibers were dissolved by vigorous stirring in DMAc at $150{ }^{\circ} \mathrm{C}$ for 3 days to give a homogeneous solution with a solid content of $5 \mathrm{wt} \%$ after filtering. In parallel, CLI, CLII and CLIII were dissolved in DMAc (5 wt\%). The solutions were mixed at different ratios to give a theoretical degree of cross-linking of $10 \%$, defined as the molar fraction of the cross-linking agents with respect to the polymer repeat unit. Membranes were cast on partially covered Petri dishes with a diameter of $11 \mathrm{~cm}$ on leveled glass plates mounted in a Memmert Universal Oven $\mathrm{U}$ at heating rate of $7{ }^{\circ} \mathrm{C} \mathrm{h}^{-1}$ up to $60^{\circ} \mathrm{C}$. It was kept at $60{ }^{\circ} \mathrm{C}$ for $6 \mathrm{~h}$ before further heating $\left(10^{\circ} \mathrm{C} \mathrm{h}^{-1}\right)$ to $120^{\circ} \mathrm{C}$ for 6 hours and finally heated $\left(10^{\circ} \mathrm{C} \mathrm{h}^{-1}\right)$ to $180{ }^{\circ} \mathrm{C}$ for $12 \mathrm{~h}$ before cooling to room temperature. The membranes were peeled off from the glass substrates in deionized water and treated twice in deionized water at $80^{\circ} \mathrm{C}$ for $1 \mathrm{~h}$, before drying at $110^{\circ} \mathrm{C}$ in vacuum overnight. The membranes were then stored at ambient conditions 
in sealed polyethylene bags until further use, and the membranes cross-linked using CLI, CLII and CLIII are hereafter referred to as PBI-CLI, PBI-CLII and PBI-CLIII, respectively.

\subsection{Characterization}

The gel content was calculated according to Eq. (1), where $\mathrm{m}_{\mathrm{i}}$ is the mass of the dry membrane sample $\left(110{ }^{\circ} \mathrm{C}\right.$ overnight in vacuum) and $\mathrm{m}_{\mathrm{f}}$ is the residual solid fraction (after washing and drying) isolated after immersion DMAc at $80{ }^{\circ} \mathrm{C}$ for 6 hours, washed twice in water at $80^{\circ} \mathrm{C}$ for 1 hour and dried at $110{ }^{\circ} \mathrm{C}$ in vacuum overnight.

Gel Content $=\left(\mathrm{m}_{\mathrm{i}}-\mathrm{m}_{\mathrm{f}}\right) / \mathrm{m}_{\mathrm{i}}$

The Fenton's test was carried out as described in literature $[25,44,45]$. The samples $(1 \times 6$ $\mathrm{cm}^{2}$ ) were dried under vacuum at $110{ }^{\circ} \mathrm{C}$ for a minimum of $16 \mathrm{~h}$ to obtain the dry weight. The samples were then immersed in an aqueous solution containing $3 \mathrm{wt} \% \mathrm{H}_{2} \mathrm{O}_{2}$ and 4 ppm $\mathrm{Fe}^{2+}$ (added as $\left.\left(\mathrm{NH}_{4}\right)_{2} \mathrm{Fe}\left(\mathrm{SO}_{4}\right)_{2} \cdot 6 \mathrm{H}_{2} \mathrm{O}\right)$ and kept at $68^{\circ} \mathrm{C}$. The weight of the samples was recorded and the solution was refreshed every 24 hours. Similarly, the phosphoric acid uptake and volume swelling was measured after drying the samples $\left(1 \times 6 \mathrm{~cm}^{2}\right)$ under vacuum at $110^{\circ} \mathrm{C}$ for at least $16 \mathrm{~h}$ to obtain the dry weigh and dimensions. The samples were then immersed in $85 \mathrm{wt} \% \mathrm{PA}$ in a closed container for $336 \mathrm{~h}$ at room temperature. After blotted dry with tissue paper, the weight and dimensions were recorded prior and after being dried at $60{ }^{\circ} \mathrm{C}$ for minimum $16 \mathrm{~h}$. The acid doping level (ADL), i.e. the number of phosphoric acid molecules per polymer repeat unit, was calculated according to Eq. (2), where $\mathrm{W}_{\mathrm{p}}$ and $\mathrm{W}_{\mathrm{d}}$ is the dry sample weight before and after doping, respectively while $\mathrm{M}_{\mathrm{PA}}$ and $\mathrm{M}_{\mathrm{PBI}}$ is the molar mass of phosphoric acid and of the PBI repeat unit. 
$\mathrm{ADL}=\left(\left(\mathrm{W}_{\mathrm{d}}-\mathrm{W}_{\mathrm{p}}\right) / \mathrm{M}_{\mathrm{PA}}\right) /\left(\mathrm{W}_{\mathrm{p}} / \mathrm{M}_{\mathrm{PBI}}\right)$

The volume swelling was calculated according to Eq. (3), where $V_{p}$ and $V_{d}$ is the volume before and after doping, respectively, calculated based on the sample dimensions (width, length and thickness).

Volume swelling $=\left(\mathrm{V}_{\mathrm{d}}-\mathrm{V}_{\mathrm{p}}\right) / \mathrm{V}_{\mathrm{p}}$

Thermogravimetric analysis in combination with differential thermal analysis (TGA/DTA) was performed using a Netzsch STA 409 PC. The samples (10-20 mg) were heated from room temperature to $1000{ }^{\circ} \mathrm{C}$ at a heating rate of $5^{\circ} \mathrm{C} \mathrm{min}-1$ using synthetic air as purge gas at a flow rate of $30 \mathrm{~mL} \mathrm{~min}^{-1}$. Fourier transform infra-red (FT-IR) data were obtained using a Perkin Elmer Spectrum Two IR spectrometer equipped with an attenuated total reflectance (ATR) accessory over 8 accumulated scans with a $4 \mathrm{~cm}^{-1}$ resolution. X-ray diffraction (XRD) data was obtained using a Rigaku Miniflex 600, operated at $40 \mathrm{kV}$ and $15 \mathrm{~mA}$ at a scan speed of 2 degrees per minute. Stress-strain curves were recorded using a universal materials testing machine (Testometric Micro 350) at a crosshead speed of $10.00 \mathrm{~mm} \mathrm{~min}^{-1}$. Five dog bone shaped samples of each type were tested after drying at $110^{\circ} \mathrm{C}$ (undoped) or $60^{\circ} \mathrm{C}$ (doped) for minimum 16 hours.

Conductivity measurements were performed using a four-probe cell. A symmetric square wave current with a frequency of $1-3 \mathrm{kHz}$ was applied through platinum foils, and the in-plane voltage drop was measured via platinum probes fixed $1 \mathrm{~cm}$ apart. The conductivity cell mounted in a glass tube and placed in an oven for temperature control. The cell was purged with air $\left(10 \mathrm{~mL} \mathrm{~min}^{-1}\right)$ that had been bubbled through water at $0{ }^{\circ} \mathrm{C}$. 
Electrodes for fuel cell testing were supplied by Danish Power Systems, with $1 \mathrm{mg} \mathrm{cm}^{-}$ 2 platinum loading, $57.3 \mathrm{wt} \% \mathrm{Pt}$ on carbon catalyst. The membrane electrode assemblies (MEA) were assembled directly in the cell housing by sandwiching $5 \times 5 \mathrm{~cm}^{2}$ membrane pieces between $50 \mu \mathrm{m}$ Kapton gaskets with $2.96 \times 2.96 \mathrm{~cm}^{2}$ holes cut for the electrodes. The $3.1 \times$ $3.1 \mathrm{~cm}^{2}$ electrodes were placed on each side of the assembly, followed by polytetrafluoroethylene (PTFE) gaskets for gas tightness.

After heating to $120^{\circ} \mathrm{C}$ with no gas flows, the cells were supplied with dry hydrogen and air at atmospheric pressure with stoichiometries of 2 and 4 respectively, based on $227 \mathrm{~mA}$ $\mathrm{cm}^{-2}$ (2 A nominal). Temperature set point was increased to $160{ }^{\circ} \mathrm{C}$ and a load of $200 \mathrm{~mA} \mathrm{~cm}^{-}$ ${ }^{2}$ was applied to the cells. The cell voltage development was recorded for during approximately $6000 \mathrm{~h}$. Electrochemical impedance spectroscopy measurements at $200 \mathrm{~mA} \mathrm{~cm}{ }^{-2}$ were performed on regular basis to detect changes in ohmic resistance. Polarization curves were recorded after 1300, 2300 and $6000 \mathrm{~h}$, with hydrogen and air flows fixed at $\lambda=2$ and 4 up to 2 A, after that the flows were increased with current, matching the above specified stoichiometries.

\section{Results and discussion}

\subsection{Membrane preparation and characterization}

To investigate the chemistry involved in the cross-linking process, a model compound synthesis was conducted (Scheme 1). Benzimidazole was chosen to represent the repeat unit of PBI and was reacted with the different bis(chloromethyl) arenes. The arene bis(benzimidazoles) were obtained in quantitative yield after refluxing in DMAc for $2 \mathrm{~h}$, and their identity was confirmed by NMR. The reaction is well-described in the literature, and takes place by $\mathrm{S}_{\mathrm{N}} 2$-type displacement $[41,46]$. 
For the cross-linking of the PBI membranes, the cross-linking agents were mixed into the membrane casting solution. $10 \mathrm{~mol} \%$ of the cross-linkers with respect to the polymer repeat unit was added, to balance the toughening versus the embrittlement observed at high degrees of cross-linking [25]. After solvent evaporation, the membranes were heated to $180{ }^{\circ} \mathrm{C}$ for 12 $\mathrm{h}$, to promote the reaction and to produce cross-linked membranes as shown in Scheme 2. Although such a solid-state process is fundamentally different from the homogeneous solution reaction to produce the model compounds, the membrane cross-linking reaction likely proceeded via a similar pathway.

The FT-IR spectra of the cross-linked membranes prepared using CLI, CLII and CLIII are shown in Figure 1a. The spectrum of pristine PBI showed the main characteristic absorption bands as assigned and discussed in more detail in the literature [47, 48]. As shown in Figure $1 \mathrm{~b}$, the chloromethyl groups of the cross-linking agents showed a strong characteristic absorption band at $650-670 \mathrm{~cm}^{-1}$. After coupling to the benzimidazole units, this band was no longer observed in the spectra of the model compounds or the cross-linked membranes, which supports that cross-linking had occurred [49]. Furthermore, the N-H stretching band at around $3410 \mathrm{~cm}^{-1}$ was significantly weakened in the spectra of the cross-linked membranes, which frequently is used as an indicator of $N$-substitution of PBI [27, 28, 47].

As a qualitative measure of the degree of cross-linking, the gel content of the membranes was determined after stirring the membranes in DMAc at $80{ }^{\circ} \mathrm{C}$ for $6 \mathrm{~h}$, as summarized in Table 1. While the reference membrane based on linear PBI readily dissolved almost completely, the cross-linked membranes showed gel contents of close to $100 \%$ as expected for a cross-linked polymer matrix. This is a clear indication that cross-linked membranes had been obtain, but as stated above the gel content is a qualitative measure and even polymer matrices with very low degrees of cross-linking can give gel contents of $100 \%$. 
As described by Liao et al. [45], the mass loss of PBI during the Fenton test is inversely proportional to the initial molecular weight over a test period of at least $280 \mathrm{~h}$. It is also common that cross-linked membranes show reduced rates of weight loss $[25,27,28]$. This does not directly imply that cross-linked membranes are inherently more oxidation resistant than their linear counterparts are, but rather indicates that soluble degradation products are formed at a lower rate. As summarized in Table 1, the membrane based on linear PBI in the present work showed a residual mass of $72 \%$ after $336 \mathrm{~h}$ in the Fenton solution. The corresponding values for the cross-linked membranes was considerably higher and ranged from $83-89 \%$, in consistence with findings in the literature $[25,28,32]$.

As shown in Figure 2, the XRD of the membrane based on linear PBI showed a broad amorphous peak around $2 \theta=24^{\circ}$ as previously reported in the literature [50]. The cross-linked membranes were apparently amorphous, although minor discrepancies in the diffraction patterns could be observed, such as a shoulder at $2 \theta=10-15^{\circ}$, due to the altered chain-packing arrangements $[50,51]$. However, as summarized in Table 1 , this did not have any pronounced effect on the $d$-spacings as calculated based on the amorphous peak maxima indicating that the inter-chain distances were virtually unaffected by the cross-linking.

The thermogravimetric curves the linear and cross-linked membranes and the corresponding model compounds are shown in Figure 3. The mass loss of the model compounds occurred in two stages between $300-400{ }^{\circ} \mathrm{C}$ and $500-650{ }^{\circ} \mathrm{C}$, which was considerably higher than that of benzimidazole and the pure cross-linking agents. The model compound prepared from CLIII showed a slightly lower onset temperature of major decomposition than the model compounds prepared from CLI or II. A small weight loss with an onset at about $370{ }^{\circ} \mathrm{C}$ was observed for the PBI-CLI and PBI-CLIII membranes, which was not present in the thermogravimetric curves of the linear PBI and PBI-CLI membranes. This is likely due to elimination of grafted groups formed by incomplete cross-linking reaction [28]. 
For linear PBI, the major onsets at about $520{ }^{\circ} \mathrm{C}$ and $588^{\circ} \mathrm{C}$ are associated with the thermooxidative degradation of the polymer backbone [52]. While the former remained nearly unchanged for the cross-linked membranes, the latter was shifted to 619 and $629^{\circ} \mathrm{C}$ for PBICLII and PBI-CLIII, respectively.

The phosphoric acid uptake and volume swelling during doping was recorded as function of immersion time in $85 \% \mathrm{H}_{3} \mathrm{PO}_{4}$, as summarized in Figure 4. The linear PBI membrane reached an equilibrium acid doping level (ADL) of about $12.5 \mathrm{H}_{3} \mathrm{PO}_{4}$ per polymer repeat unit after one day. The phosphoric acid uptake was accompanied by a volume swelling of $250 \%$, which is in good agreement with literature data for PBI at similar acid contents [8]. Compared with that of the linear PBI membrane, the phosphoric acid uptake of the PBI-CLI and PBI-CLII membranes was considerably slower. The doping was initially highly inhomogeneous, as revealed by the large standard deviation during the initial doping period. The equilibrium ADLs were reached after 6 days and corresponded to 9.3 and $9.8 \mathrm{H}_{3} \mathrm{PO}_{4}$ per polymer repeat unit for PBI-CLI and PBI-CLII, respectively. The doping behavior of the PBICLIII membrane was similar to that of the membrane based on linear PBI, reaching an equilibrium $\mathrm{ADL}$ of $11.3 \mathrm{H}_{3} \mathrm{PO}_{4}$ per polymer repeat unit after one day. This may indicate that the real degree of cross-linking for the PBI-CLIII membrane was lower than that of the PBICLI and PBI-CLII membranes. This is a plausible explanation since the steric nature of the CLIII likely reduces its reactivity in nucleophilic displacement reactions. This steric effect is not present in CLI and CLII, which may explain their higher apparent degree of effective crosslinking as indicated by their lowered acid uptakes.

However, the specific swelling [8] for all cross-linked membranes (Table 2) was lower than that of the membrane based on linear PBI, indicating restricted swelling as a direct consequence of the cross-linking. Furthermore, the $\mathrm{N}$-functionalization of the benzimidazole 
units likely suppressed their hydrogen-bonding ability which in turn could weaken their interaction with the phosphoric acid.

Representative stress-strain curves of the phosphoric acid doped membranes based on linear and cross-linked PBI are shown in Figure 5 and the corresponding elastic modulus data are summarized in Table 2. The reference membrane showed typical stress-strain behavior for phosphoric acid doped linear PBI, with an elastic modulus of $92 \mathrm{MPa}$. The elastic modulus of the cross-linked membranes was higher than that of the linear PBI membrane, accompanied by a lower strain at break. This is a characteristic feature of cross-linked polymer matrices, but could also partly be explained by the slightly lower acid contents. The yield points of the crosslinked membranes were also higher than that of the linear PBI membrane, showing the increased mechanical toughness. The acid doping behavior of the PBI-CLI and PBI-CLII membranes were similar but PBI-CLI showed slightly lower acid uptake than PBI-CLII and large resistance towards plastic deformation as indicated by the higher slope of the stress-strain curve beyond the yield point. It is evident that the steric nature and regio-chemistry of the crosslinking agent affects the effective degree of cross-linking obtained. In this work, the highest effective degree of cross-linking was obtained using the linear and non-steric para-substituted cross-linking agent CLI. The effective degree of cross-linking was slightly lowered when the meta-substituted CLII was used and the lowest effective degree of cross-linking was obtained with the steric meta-substituted derivative (CLIII).

\subsection{Conductivity, fuel cell performance and durability}

The proton conductivity of the membrane based on linear PBI was slightly above $0.1 \mathrm{~S} \mathrm{~cm}^{-1}$ at $160{ }^{\circ} \mathrm{C}$, in consistence with data in the literature for membranes of similar phosphoric acid contents $[8,53]$. The acid content of the PBI-CLIII was comparable to that of the linear PBI membrane and the conductivity was thus similar. The acid content of the PBI-CLI and PBI- 
CLII membranes was about $25 \%$ lower, which was reflected by a significantly lower conductivity of $35-59 \mathrm{mS} \mathrm{cm}^{-1}$.

In order to assess the membranes under real operating conditions, fuel cell MEAs were prepared based on the membranes with $10 \%$ degree of cross-linking and operated at $160{ }^{\circ} \mathrm{C}$ and $200 \mathrm{~mA} \mathrm{~cm}^{-2}$. A technical problem with the data acquisition occurred during the test, which caused loss of data during parts of the durability tests but did not influence the cell operation parameters. The voltage evolution curves are shown in Figure 6, showing a general increase in cell voltage during the first $500 \mathrm{~h}$ of operation. This is due to initial redistribution of the acid in the catalyst layers as discussed in more detail elsewhere [12]. After the break-in period, the cell voltages peaked at 666, 645, 661 and $664 \mathrm{mV}$ for the cells based on PBI, PBI-CLI, PBICLII and PBI-CLIII, respectively. The cell voltage subsequently declined in an apparently linear manner. After about $6000 \mathrm{~h}$ of operation the cell voltage was $628,617,616,635 \mathrm{mV}$ for the cells based on PBI, PBI-CLI, PBI-CLII and PBI-CLIII, respectively. For the reference cell based on the linear PBI membrane, it corresponds to an average cell voltage decay rate of 6.7 $\mu \mathrm{V} \mathrm{h}^{-1}$, which is in good agreement with data in the literature for cells operated under similar conditions [12]. The corresponding average cell voltage decay rate for the cells based on PBICLI, PBI-CLII and PBI-CLIII was 5.3, 8.0 and 5.1 $\mu \mathrm{V} \mathrm{h}^{-1}$.

The polarization curves recorded after about 1300, 2300 and $6000 \mathrm{~h}$ of operation are shown in Figure 7. In the beginning of the test period $(1300 \mathrm{~h})$, the open circuit voltage OCV for the cells based on PBI-CLI, PBI-CLII and PBI-CLIII, respectively the 947, 996, 993 and $986 \mathrm{mV}$. Although the linear PBI membrane was slightly thicker $(97 \mu \mathrm{m})$ than the cross-linked membranes (PBI-CLI: $85 \mu \mathrm{m}$, PBI-CLII: $92 \mu \mathrm{m}$, PBI-CLIII: $88 \mu \mathrm{m}$ ), the OCV was 33-46 mV lower. It could be interpreted as lower gas permeability for the cross-linked membranes. For PBI-CLI and PBI-CLII this could be explained by the lower acid uptakes and reduced lower swelling. However, the acid uptake and volume swelling for the PBI-CLIII membrane was only 
marginally lower than that of PBI-CLIII, which supports that increased OCV is a result of the cross-linking.

In the higher current density regime, the cells showed significant differences. For example, after $1300 \mathrm{~h}$ the cell voltage for the cells based on PBI, PBI-CLI, PBI-CLII and PBICLIII was 550, 485, 501 and $547 \mathrm{mV}$ at $567 \mathrm{~mA} \mathrm{~cm}^{-2}$ and 410, 262, 311 and $405 \mathrm{mV}$ at 1136 $\mathrm{mA} \mathrm{cm}{ }^{-2}$, respectively. The cells based on PBI-CLI and PBI-CLII showed significantly lower cell voltage than the cells based on linear PBI and PBI-CLIII. This is a direct consequence of the lower acid uptake (Figure 4), which result in lower conductivity (Table 2) and manifests in the form of increased ohmic voltage loss in the fuel cell.

After $6000 \mathrm{~h}$ of operation at $200 \mathrm{~mA} \mathrm{~cm}^{-2}$, the OCV for the cells based on PBI, PBICLI, PBI-CLII and PBI-CLIII was 943, 1005, 1002 and $991 \mathrm{mV}$, respectively. At the same time, the cell voltages for the cells based on PBI, PBI-CLI, PBI-CLII and PBI-CLIII was 512, 434, 440 and $507 \mathrm{mV}$ at $567 \mathrm{~mA} \mathrm{~cm}^{-2}$ and 359, 191, 193 and $344 \mathrm{mV}$ at $1136 \mathrm{~mA} \mathrm{~cm}{ }^{-2}$, respectively. This leads us to conclude that the predominating degradation mode is connected to acid loss, resulting in increased ohmic resistance of the membrane and a more dense membrane structure with a reduced gas permeability. This seems further supported by the area specific resistance (ASR) data extracted from the electrochemical impedance spectroscopy data, as shown in Figure 8a. For the cell based on linear PBI, the ASR decreased slightly during the initial break-in period which in good agreement with the data shown in Figure 6. After about 500 hours, it was $113 \mathrm{~m} \Omega \mathrm{cm}^{2}$ and consistent with data in the literature for membranes with similar acid doping levels [12]. Assuming that the ohmic loss in the membranes predominates over the other ohmic contributions, it corresponds to an in-situ conductivity of around $86 \mathrm{mS} \mathrm{cm}^{-1}$ (Figure $8 \mathrm{~b}$ ). After $6000 \mathrm{~h}$, the ASR had increased to $136 \mathrm{~m} \Omega \mathrm{cm}^{2}$ and the corresponding in-situ conductivity of around $71 \mathrm{mS} \mathrm{cm}$, assuming that the membrane thickness was unchanged. The ASR of the cells based on the PBI-CLI and PBI-CLII after 500 
h was 192 and $162 \mathrm{~m} \Omega \mathrm{cm}^{2}$, respectively, which is in good agreement with the significantly higher ohmic loss compared with the linear PBI revealed by the polarization data (Figure 7a). As described above, this is mainly due to the lower acid doping levels. After $6000 \mathrm{~h}$, the ASR of the PBI-CLI and PBI-CLII cells was similar $\left(219 \mathrm{~m} \Omega \mathrm{cm}^{2}\right)$ which shows that the ASR of the PBI-CLII increased faster than that of PBI-CLI. The initial ASR of the cell based on PBICLIII was slightly higher than that of the linear PBI cell $\left(127 \mathrm{~m} \Omega \mathrm{cm}^{2}\right)$, but in contrast to the other cells based on the cross-linked membranes the ASR evolution followed that of the cell based on linear PBI. It should be remarked that membrane thinning during the first $6000 \mathrm{~h}$, which can be in the range of $20-30 \%$ [12], could compensate for eventual conductivity decay due to acid loss and result in an underestimation of the in-situ conductivity changes.

It is clear that the initial fuel cell performance data correlated well with the acid content of the membranes. Higher acid loadings lead to higher proton conductivities and therefore lower ohmic losses. The equilibrium acid doping level of the PBI-CLI and PBI-CLII was significantly lower than that of the membrane based on linear PBI, and nearly $200 \mathrm{~h}$ were required to reach equilibrium at room temperature. Increasing area specific resistance is mainly correlated to acid loss from the membrane [14], and the higher degradation rates of the fuel cells based on PBI-CLI and PBI-CLII is likely a consequence of the rigid cross-linked structure promoting acid leaching. The $N$-functionalization of the benzimidazole is also likely weakening the polymer-phosphoric acid interaction, which could further promote the acid leaching. The cell based on the PBI-CLIII membrane showed performance a performance and degradation behavior that was similar to that of the linear PBI based cell. This is likely due to the bulky structure of the cross-linking agent, giving a stronger plasticizing effect and a lower effective degree of cross-linking and therefor better acid retention characteristics. However, our recent work [12] indicate that test durations exceeding $10000 \mathrm{~h}$ may be needed to reveal 
trends in the degradation behavior under mild operating conditions at $160{ }^{\circ} \mathrm{C}$ and at constant intermediate current loads.

\section{Conclusions}

Cross-linked polybenzimidazole membrane were prepared using three bis(chloromethyl) arene derivatives. The regio-chemistry and steric nature of the cross-linking agents affect the effective degree of cross-linking, which in turn determines the doping characteristics in phosphoric acid. All cross-linked membranes showed enhanced chemical stability, but the rigid cross-linked membranes showed low acid uptake and reduced acid retention characteristics. The membrane cross-linked with a steric bulky group showed plastic behavior and fuel cell performance and acid retention characteristics comparable to that of the membrane based on linear PBI during the $6000 \mathrm{~h}$ cell test. Further extended test durations or accelerated test protocols are likely needed to clearly reveal trends in the degradation behavior as a basis for recommendations regarding the further development directions.

\section{Acknowledgements}

This work was financially supported by Innovation Fund Denmark (KDFuelCell, 304700007B) and 4M Center (0603-00527B).

\section{References}

[1] Q. Li, J.O. Jensen, R.F. Savinell, N.J. Bjerrum, Prog. Polym. Sci. 2009, 34, 449.

[2] E. Quartarone, P. Mustarelli, Energy Environ. Sci. 2012, 5, 6436.

[3] J.K. Kallitsis, M. Geormezi, S.G. Neophytides, Polym. Int. 2009, 58, 1226.

[4] J.S. Wainright, J.T. Wang, D. Weng, R.F. Savinell, M. Litt, J. Electrochem. Soc. 1995, 142, L121. 
[5] C. Pan, R. He, Q. Li, J.O. Jensen, N.J. Bjerrum, H.A. Hjulmand, A.B. Jensen, J. Power Sources 2005, 145, 392.

[6] Q. Li, R.H. He, J.O. Jensen, N.J. Bjerrum, Chem. Mater. 2003, 15, 4896.

[7] Q. Li, R.H. He, J.O. Jensen, N.J. Bjerrum, Fuel Cells 2004, 4, 147.

[8] J. Yang, L.N. Cleemann, T. Steenberg, C. Terkelsen, Q. Li, J.O. Jensen, H.A. Hjuler, N.J. Bjerrum, R. He, Fuel Cells, 2014, 14, 7.

[9] S.H. Eberhardt, M. Toulec, F. Marone, M. Stampanoni, F.N. Büchi, T.J. Schmidt, J. Electrochem. Soc. 2015, 162, F310.

[10] H. Becker, L.N. Cleemann, D. Aili, J.O. Jensen, Q. Li, Electrochem. Commun. 2017, 82, 21.

[11] D. Aili, J. Zhang, M.T. Dalsgaard Jakobsen, H. Zhu, T. Yang, J. Liu, M. Forsyth, C. Pan, J.O. Jensen, L.N. Cleemann, S.P. Jiang, Q. Li, J. Mater. Chem. A 2016, 4, 4019.

[12] T. Søndergaard, L.N. Cleemann, H. Becker, D. Aili, T. Steenberg, H.A. Hjuler, L. Seerup, Q. Li, J.O. Jensen, J. Power Sources 2017, 342, 570.

[13] S.H. Eberhardt, T. Lochner, F.N. Büchi, T.J. Schmidt, J. Electrochem. Soc. 2015, 162, F1367.

[14] T. Søndergaard, L.N. Cleemann, H. Becker, T. Steenberg, H.A. Hjuler, L. Seerup, Q. Li, J.O. Jensen, J. Electrochem. Soc. 2018, 165, F3053.

[15] J. Lobato, P. Cañizares, M.A. Rodrigo, D. Úbeda, F.J. Pinar, ChemSusChem 2011, 4, 1489.

[16] F.J. Pinar, P. Cañizares, M.A. Rodrigo, D. Ubeda, J. Lobato, RSC Adv. 2012, 2, 1547.

[17] F.J. Pinar, P. Cañizares, M.A. Rodrigo, D. Úbeda, J. Lobato, J. Power Sources 2015, 274, 177.

[18] J. Zhang, D. Aili, J. Bradley, H. Kuang, C. Pan, R. De Marco, Q. Li, S.P. Jiang, J. Electrochem. Soc. 2017, 164, F1615. 
[19] J. Luo, A.H. Jensen, N.R. Brooks, J. Sniekers, M. Knipper, D. Aili, Q. Li, B. Vanroy, M. Wübbenhorst, F. Yan, L. Van Meervelt, Z. Shao, J. Fang, Z.-H. Luo, D.E. De Vos, K. Binnemans, J. Fransaer, Energy Environ. Sci. 2015, 8, 1276.

[20] R. He, Q. Li, A. Bach, J.O. Jensen, N.J. Bjerrum, J. Membr. Sci. 2006, 277, 38.

[21] Q. Li, J.O. Jensen, C. Pan, V. Bandur, M.S. Nilsson, F. Schönberger, A. Chromik, M. Hein, T. Häring, J. Kerres, N.J. Bjerrum, Fuel Cells 2008, 8, 188.

[22] J. Lobato, P. Cañizares, M.A. Rodrigo, J.J. Linares, J.A. Aguilar, J. Membr. Sci. 2007, $306,47$.

[23] H.-L. Lin, Y.-C. Chen, C.-C. Li, C.-P. Cheng, T.L. Yu, J. Power Sources 2008, 181, 228. [24] D. Aili, L.N. Cleemann, Q. Li, J.O. Jensen, E. Christensen, N.J. Bjerrum, J. Mater. Chem. 2012, 22, 5444 .

[25] Q. Li, C. Pan, J.O. Jensen, P. Noyé, N.J. Bjerrum, Chem. Mater. 2007, 19, 350.

[26] J. Yang, H. Jiang, L. Gao, J. Wang, Y. Xu, R. He, Int. J. Hydrogen Energy 2018, 43, 3299.

[27] P. Noyé, Q. Li, C. Pan, N.J. Bjerrum, Polym. Adv. Technol. 2008, 19, 1270.

[28] D. Aili, Q. Li, E. Christensen, J.O. Jensen, N.J. Bjerrum, Polym. Int. 2011, 60, 1201.

[29] M. Han, G. Zhang, Z. Liu, S. Wang, M. Li, J. Zhu, H. Li, Y. Zhang, C.M. Lew, H. Na, J. Mater. Chem. 2011, 21, 2187.

[30] S. Wang, C. Zhao, W. Ma, G. Zhang, Z. Liu, J. Ni, M. Li, N. Zhang, H. Na, J. Membr. Sci. 2012, 411-412, 54.

[31] H.-L. Lin, Y.-C. Chou, T.L. Yu, S.-W. Lai, Int. J. Hydrogen Energy 2012, 37, 383.

[32] J. Yang, Y. Xu, P. Liu, L. Gao, Q. Che, R. He, Electrochim. Acta 2015, 160, 281.

[33] P. Sun, Z.F. Li, S.W. Wang, X.Y. Yin, J. Membr. Sci. 2018, 549, 660.

[34] J. Yang, L. Gao, J. Wang, Y. Xu, C. Liu, R. He, Macromol. Chem. Phys. 2017, 218, 10.

[35] H. Luo, H. Pu, Z. Chang, D. Wan, H. Pan, J. Mater. Chem. 2012, 22, 20696. 
[36] A. Kirkebæk, D. Aili, D. Henkensmeier, J.O. Jensen, Q. Li, Macromol. Mater. Eng. 2017, 1700347.

[37] J. Yang, Q. Li, L.N. Cleemann, J.O. Jensen, C. Pan, N.J. Bjerrum, R. He, Adv. Energy Mater. 2013, 3, 622.

[38] J. Kerres, V. Atanasov, Int. J. Hydrogen Energy 2015, 40, 14723.

[39] D. Joseph, N.N. Krishnan, D. Henkensmeier, J.H. Jang, S.H. Choi, H.-J. Kim, J. Han, S.W. Nam, J. Mater. Chem. A 2017, 5, 409.

[40] N.N. Krishnan, D. Joseph, N.M.H. Duong, A. Konovalova, J.H. Jang, H.-J. Kim, S.W. Nam, D. Henkensmeier, J. Membr. Sci. 2017, 544, 416.

[41] J. Yang, D. Aili, Q. Li, L.N. Cleemann, J.O. Jensen, N.J. Bjerrum, R. He, ChemSusChem 2013, 6, 275.

[42] S.K. Kim, S.W. Choi, W.S. Jeon, J.O. Park, T. Ko, H. Chang, J.C. Lee, Macromolecules 2012, 45,1438 .

[43] S. Wang, C. Zhao, W. Ma, N. Zhang, Z. Liu, G. Zhang, H. Na, J. Power Sources 2013, $243,102$.

[44] D. Aili, M.K. Hansen, C. Pan, Q. Li, E. Christensen, J.O. Jensen, N.J. Bjerrum, Int. J. Hydrogen Energy 2011, 36, 6985.

[45] J.H. Liao, Q.F. Li, H.C. Rudbeck, J.O. Jensen, A. Chromik, N.J. Bjerrum, J. Kerres, W. Xing, Fuel Cells 2011, 11, 745.

[46] J. Yang, D. Aili, Q. Li, Y. Xu, P. Liu, Q. Che, J.O. Jensen, N.J. Bjerrum, R. He, Polym. Chem. 2013, 4, 4768.

[47] K.Y. Wang, Y.C. Xiao, T.S. Chung, Chem. Eng. Sci. 2006, 61, 5807.

[48] Q. Li, R. He, R.W. Berg, H.A. Hjuler, N.J. Bjerrum, Solid State Ionics 2004, 168, 177.

[49] T. Weissbach, A.G. Wright, T.J. Peckham, A. Sadeghi Alavijeh, V. Pan, E. Kjeang, S. Holdcroft, Chem. Mater. 2016, 28, 8060. 
[50] S.C. Kumbharkar, M.N. Islam, R.A. Potrekar, U.K. Kharul, Polymer 2009, 50, 1403.

[51] J. Lobato, P. Cañizares, M.A. Rodrigo, J.J. Linares, G. Manjavacas, J. Membr. Sci. 2006, $280,351$.

[52] D. Aili, K. Jankova, Q. Li, N.J. Bjerrum, J.O. Jensen, J. Membr. Sci. 2015, 492, 422.

[53] D. Aili, I. Javakhishvili, J. Han, K. Jankova, C. Pan, S. Hvilsted, J.O. Jensen, N.J. Bjerrum, Q. Li, Macromol. Chem. Phys. 2016, 217, 1161.

\section{Figure captions:}

Scheme 1: Reaction scheme for the preparation of the model compounds and the chemical structures of the cross-linking agents.

Scheme 2: Structures of the cross-linked PBI membranes using CLI, CLII and CLIII assuming complete conversion.

Figure 1: FT-IR spectra of linear and cross-linked PBI (a) and of the individual cross-linking agents and the corresponding model compounds (b) as solid and dotted lines, respectively.

Figure 2: XRD of the membranes based on linear and cross-linked PBI.

Figure 3: Thermogravimetric curves for linear and cross-linked PBI (solid lines) and the corresponding model compounds (dotted lines).

Figure 4: Phosphoric acid uptake normalized as $\mathrm{H}_{3} \mathrm{PO}_{4}$ per polymer repeat unit and corresponding volume swelling recorded at functions of time for the membranes based on linear and cross-linked PBI. 
Figure 5: Representative stress-strain curves of the phosphoric acid doped membranes.

Figure 6: Cell voltage evolution at a current load of $200 \mathrm{~mA} \mathrm{~cm}^{-2}$ at $160{ }^{\circ} \mathrm{C}$ for cells based on PBI (a), PBI-CLI (b), PBI-CLII (c) and PBI-CLIII (d).

Figure 7: Polarization curves (solid lines) and corresponding power densities (dashed lines) of the fuel cells based on phosphoric acid doped PBI, PBI-CLI, PBI-CLII and PBI-CLIII after $1300 \mathrm{~h} \mathrm{(a),} 2300 \mathrm{~h} \mathrm{(b)}$ and $6000 \mathrm{~h}(\mathrm{c})$ of operation at $160{ }^{\circ} \mathrm{C}$ and at a constant current load of $200 \mathrm{~mA} \mathrm{~cm}^{-2}$.

Figure 8: Area specific resistance (a) and in-situ conductivity (b) as functions of time of the fuel cells based on phosphoric acid doped PBI, PBI-CLI, PBI-CLII and PBI-CLIII extracted from electrochemical impedance spectroscopy (taken as the high frequency $Z_{r e}$ intercept) data recorded at $200 \mathrm{~mA} \mathrm{~cm}^{-2}$. The calculations are based on the initial membrane thicknesses. 
Table 1 Gel contents, Fenton test residues and $d$ spacings calculated based on XRD data for the membranes of linear and cross-linked PBI.

\begin{tabular}{llll}
\hline Membrane & Gel content $/ \mathrm{wt} \%$ & Residue after 336 h Fenton test / wt \% & $d$-spacing / $~$ \\
\hline PBI & 12.3 & 71.6 & 3.66 \\
PBI-CLI & 98.3 & 88.8 & 3.60 \\
PBI-CLII & 94.4 & 82.8 & 3.65 \\
PBI-CLIII & 92.6 & 88.8 & 3.51 \\
\hline
\end{tabular}

Table 2 Summary of specific swelling, elastic modulus and proton conductivity at $160{ }^{\circ} \mathrm{C}$ for the membranes based on linear and cross-linked PBI. The equilibrium ADLs for the corresponding membranes were as shown in Figure 4.

\begin{tabular}{llll}
\hline Membrane & Specific swelling $/ \% \mathrm{ADL}^{-1}$ & Elastic modulus $/ \mathrm{MPa}$ & $\sigma$ at $160{ }^{\circ} \mathrm{C} / \mathrm{S} \mathrm{cm}^{-1}$ \\
\hline PBI & 20.2 & $92 \pm 2$ & 0.11 \\
PBI-CLI & 19.3 & $122 \pm 28$ & 0.059 \\
PBI-CLII & 19.2 & $199 \pm 11$ & 0.035 \\
PBI-CLIII & 18.6 & $145 \pm 22$ & 0.11 \\
\hline
\end{tabular}

